IZA DP No. 7061

Domestic Multinationals, Foreign Affiliates, and Labour Demand Elasticities

Olivier N. Godart

Holger Görg

David Greenaway

December 2012 


\title{
Domestic Multinationals, Foreign Affiliates, and Labour Demand Elasticities
}

\author{
Olivier N. Godart \\ Kiel Institute for the World Economy \\ and University of Kiel \\ Holger Görg \\ Kiel Institute for the World Economy, \\ University of Kiel, GEP and IZA \\ David Greenaway \\ University of Nottingham and GEP
}

Discussion Paper No. 7061

December 2012

\author{
IZA \\ P.O. Box 7240 \\ 53072 Bonn \\ Germany \\ Phone: +49-228-3894-0 \\ Fax: +49-228-3894-180 \\ E-mail: iza@iza.org
}

\begin{abstract}
Any opinions expressed here are those of the author(s) and not those of IZA. Research published in this series may include views on policy, but the institute itself takes no institutional policy positions. The IZA research network is committed to the IZA Guiding Principles of Research Integrity.

The Institute for the Study of Labor (IZA) in Bonn is a local and virtual international research center and a place of communication between science, politics and business. IZA is an independent nonprofit organization supported by Deutsche Post Foundation. The center is associated with the University of Bonn and offers a stimulating research environment through its international network, workshops and conferences, data service, project support, research visits and doctoral program. IZA engages in (i) original and internationally competitive research in all fields of labor economics, (ii) development of policy concepts, and (iii) dissemination of research results and concepts to the interested public.
\end{abstract}

IZA Discussion Papers often represent preliminary work and are circulated to encourage discussion. Citation of such a paper should account for its provisional character. A revised version may be available directly from the author. 
IZA Discussion Paper No. 7061

December 2012

\section{ABSTRACT}

\section{Domestic Multinationals, Foreign Affiliates, and Labour Demand Elasticities}

Using information on a panel of multinational firms operating in the United Kingdom from 1996 to 2005, we find that labour demand in domestic multinationals is less sensitive to labour cost changes than in foreign multinationals. This difference in the wage elasticity of labour demand persists even when we control for the skill intensity of firms or their level of intangible assets. This is in line with an interpretation that the provision of headquarter services in domestic multinational firms protects against strong fluctuations in labour demand. Overall, our results suggest that the wage elasticity of labour demand is about 40 percent lower in domestic than in foreign multinationals.

JEL Classification: F23, J23, J24

Keywords: labour demand elasticity, multinational firms, headquarter services, skill intensity

Corresponding author:

Holger Görg

Kiel Institute for the World Economy

Hindenburgufer 66

D-24105 Kiel

Germany

E-mail: holger.goerg@ifw-kiel.de

\footnotetext{
* We would like to thank an anonymous referee, seminar participants at Nottingham, the Kiel Institute and the ETSG conference in Warsaw for their comments and suggestions. All remaining errors are our own. Olivier Godart is thankful to the Leverhulme Centre for Research on Globalisation and Economic Policy for a GEP PhD scholarship.
} 


\section{Introduction}

A general concern about multinational firms in developed countries is that they export activities abroad and substitute employees even in response to small labour cost changes (Horst, 1978; Barba-Navaretti et al., 2003). In other words, their operations may be regarded as highly footloose. Such a link between multinational firms and highly wage elastic labour demand is said to contribute to labour market instability (Rodrik, 1997; Scheve and Slaughter, 2004). This argument, however, has been criticized because multinationals possess extensive skill intensive activities in domestic headquarters which shape multinationals' competitive advantage (Markusen et al., 1995; Hanson et al., 2003) and arguably also the elasticity of their labour demand.

Thus far, however no empirical analysis has looked at the potential protecting role of headquarter activities for labour demand elasticity estimations, despite the evidence that skill intensity reduces the wage elasticity of labour demand (Hamermesh, 1993). This paper presents a first attempt to close this gap in the literature. More specifically, we investigate differences in labour demand adjustment in domestic multinationals compared to affiliates of foreign firms, using firm level data for the United Kingdom. We attribute any differences in labour demand elasticities between the two groups of firms to the role of headquarter activities in domestic multinationals.

Indeed, although domestic and foreign multinationals have many characteristics in common - they are both located in the same country, and both have access to some firmspecific asset - domestic multinational firms by definition have their headquarters in the domestic economy. By contrast, foreign owned multinational firms are generally affiliates, with headquarters located abroad. This may have important implications for labour demand adjustments. 
Headquarter services are intangible inputs which are characterized by tradability and some aspects of public goods, and they are the most skill intensive activities of a multinational (Markusen, 2002). They might be used by foreign affiliates but are generally assumed to be generated in the home country of a multinational (Davies, 2005). Foreign affiliates use these skill intensive inputs generated in the home country and combine them with local factors of production. ${ }^{1}$ Hence, we may expect that the headquarter activities of domestic multinationals are related to labour demand that is less responsive to changes in wage rates, i.e., their wage elasticity of labour demand is lower than in affiliates of foreign firms.

There are a number of papers that look at differences in labour demand elasticities between multinationals and non-multinationals or in foreign and domestic firms. In a recent contribution, Nilsson Hakkala et al. (2010) look at such differences between multinationals and non-multinationals using firm level data for Sweden. They find that wage elasticities are higher in multinationals than in domestic firms, in line with the perception that multinationals are more footloose. However, as they do not distinguish foreign and domestic multinationals but only estimate an average wage elasticity for all multinationals, they may overstate the wage elasticity for domestic multinationals and understate that for foreign firms.

Nilson Hakkala et al. (2010) define a multinational firm as domestic firms with affiliates abroad (domestic multinational) or foreign affiliates of multinationals headquartered abroad (foreign multinational). This is in contrast to a number of earlier studies, which only consider differences in wage elasticities of labour demand between foreign multinationals and domestic firms and that do not distinguish domestic multinationals from purely domestic firms (e.g., Barba Navaretti et al., 2003, Görg et al.,

\footnotetext{
${ }^{1}$ Examples of headquarter services include patents or trademarks transferred abroad but generated by R\&D activities at home, organizational capabilities to plan and coordinate activities in different markets, or more generally, any skill intensive activity, that contributes to production or distribution in foreign affiliates.
} 
2009). Barba Navaratti et al. (2003) hypothesize that foreign firms may be more volatile employers and hence they should be less rigid in their labour demand elasticity when compared to the average domestic firm. They find mixed results. In some countries the hypothesis holds but in others the opposite is true. This may be partly explained by the fact that they compare foreign firms with all domestic firms, and do not distinguish the latter into multinationals and non-multinationals. Görg et al. (2009) in a study using firm level data for Ireland find clear evidence that labour demand elasticity is higher in foreign than in domestic firms, a finding in line with Nilsson Hakkala et al. (2010). However, Görg et al. (2009) can also not say anything about labour demand elasticities in domestic multinationals vis-à-vis that of foreign firms.

In sum, none of these firm level studies allow for the fact that domestic multinationals may adjust labour demand quite differently from affiliates of foreign firms due to their headquarter activities. However, this is an important issue from a policy point of view. As Crisuolo and Martin (2009) show, the number of plants belonging to foreign and domestic multinationals is roughly similar in the United Kingdom. They each account for about 2 percent of plants, 21 percent of employment and just over a quarter of value added in the population of manufacturing plants in the UK. ${ }^{2}$ Hence, investigating whether these types of firms adjust labour demand differently is an empirically important question.

This is the issue we address in this paper using firm level data for the UK. By doing so, our study adds to the existing literature in a number of ways: Firstly, our data allows us to distinguish foreign multinationals from domestic multinationals. Using firm-level data for the UK manufacturing sector from 1996 to 2005 we are, thus able to explore differences in labour demand elasticities between foreign and domestic multinationals. We find that labour demand elasticity in domestic multinationals is significantly lower (in absolute

\footnotetext{
${ }^{2}$ Note that the empirical analysis in Criscuolo and Martin (2009) is based on a sample, not the population of plants, in which the two types of multinationals are overrepresented.
} 
terms) than in foreign multinationals, as expected. Secondly, we investigate whether this difference in the wage elasticity is driven by differences in measurable firm level skill intensities. Whereas we find that skill intensity is negatively associated with wage elasticity (in absolute terms), it is also the case that even when controlling for firm-level skill differences in two different ways, labour demand in domestic multinationals is still less wage sensitive than in foreign multinational firms. Thirdly, this difference in wage elasticity is also robust to the inclusion of the share of intangible assets in total sales. This variable is by nature strongly related to headquarter services and skill intensity. Our econometric results are economically significant. On average, labour demand elasticities are about 40 percent lower in domestic multinationals than in affiliates of foreign-owned firms based in the UK. This finding is consistent with the view that the presence of headquarter services reduces substantially the exposure of labour demand to own labour cost shocks.

In the following section, we discuss the background to our analysis. In section 3, we specify our empirical strategy and then introduce our data in section 4 . In section 5, our results are presented and in the last section we provide conclusions.

\section{Background}

We estimate labour demand elasticities in domestic and foreign multinationals operating in the UK. Our argument for considering only multinational firms is that both types of firms share a number of characteristics that make firms become multinational rather than stay on domestic markets only. In the parlance of the recent heterogeneous firm type models, these firms both have had to overcome sunk costs of FDI and therefore have to be firms that are "better" along a range of characteristics than purely domestic firms (Helpman et al., 2004, Criscuolo and Martin, 2009). While they are similar in terms of firm 
characteristics, one important difference remains: domestic multinationals have their headquarters in the UK, while foreign multinationals have them abroad. Hence, one plausible explanation for any observable difference in labour demand elasticity between foreign and domestic multinationals may be the nature of headquarter services, which are by nature skill intensive activities. ${ }^{3}$

The literature focusing on what explains multinational production has emphasized that headquarter services are central to the setting up of a foreign affiliate (e.g., Helpman, 1985). In Helpman et al. (2004), headquarter services, modeled as fixed foreign investment costs, are only payed for by the most productive firms which are, in turn, the only domestic firms to produce in multiple countries. Thus domestic multinationals devote important resources to headquarter services which contribute to their relative competitive strength. This idea is reinforced with regard to labour demand in headquarters of multinationals by Hanson et al. (2005). In their study, research and development activities contribute to the multinational-wide competitive advantage and are likely to translate into more rigid employment behaviour in response to labour cost shocks. They show that research and development employees are wage inelastic, but are unable to consider the role of headquarter services over and above those skill intensive activities. Indeed, they limit their study exclusively to domestic US multinationals and information on research and development employees is often missing.

In order to capture the potential influence of differences in the skill intensity of production processes, we not only introduce a distinct wage elasticity of labour demand in

\footnotetext{
${ }^{3}$ However, we do not want to exaggerate the importance of headquarter activities for our findings, as these are not fully observable to us. Hence, our results reported below are consistent with the conjectured role of headquarter services, but we cannot ultimately prove the validity of our interpretation. One alternative explanation may be that foreign affiliates have a larger share of labour in their variable costs when compared to domestic multinationals as proposed by Görg et al. (2009). Indeed, for a given wage shock, the magnitude of the employment changes would be proportional to the labour share in variable costs. While this argument is plausible, regressing a productivity variable on labour and total assets measures does not provide any significant difference between domestic and foreign multinational firms (results not reported to save space). Hence, this argument appears not appropriate for our data.
} 
domestic and foreign multinationals, but also include in the same specification the direct impact of skill intensity on labour demand elasticity. Furthermore, in an attempt to measure the possible importance of headquarter services we also use information on each multinational firm's intangible assets. This variable, among others, is closely linked to headquarter services and thus might affect the wage elasticity in domestic and foreign multinationals. It is, of course, difficult to measure intangible inputs, which is often thought to be a weakness in empirical studies related to MNEs (Lipsey, 2008). Intangible assets, as found in balance sheets are unlikely to measure adequately the intangible nature of headquarter services that flow across borders.

To sum up, we would expect a statistically significantly lower (in absolute terms) wage elasticity for domestic multinationals compared to foreign multinationals. This may be due to the role of headquarter activities in domestic multinationals.

\section{Empirical Approach}

We examine the expected differences in labour demand elasticities between domestic and foreign multinationals using a standard dynamic labour demand framework. In order to formalize our estimation, we derive labour demand for a multinational firm based on a generalized cost function, following Hamermesh (1993). ${ }^{4}$

Assume that a firm uses $\mathrm{n}$ factors of production $\mathrm{X}_{1} \ldots \mathrm{X}_{\mathrm{n}}$ including all foreign factors of production. One can write a production function:

$$
Y_{i}=f\left(X_{1 i}, \ldots, X_{n i}\right), f_{i} \geq 0, f_{i i} \leq 0
$$

Then, the related cost function, obtained from the demand of each $X_{1}$ to $X_{n}$ is:

$$
\mathrm{C}_{\mathrm{i}}=\mathrm{g}\left(\mathrm{s}_{1 \mathrm{i}}, \ldots, \mathrm{s}_{\mathrm{ni}}, \mathrm{Y}\right), \mathrm{g}_{\mathrm{i}} \geq 0
$$

where $s_{\mathrm{i}}$ to $\mathrm{s}_{\mathrm{n}}$ represent all input prices. Applying Shepard's lemma we derive:

$$
\mathrm{X}_{\mathrm{i}}=\mathrm{X}_{\mathrm{i}}^{\mathrm{d}}\left(\mathrm{s}_{\mathrm{i}}, \mathrm{s}_{\mathrm{n}}, \mathrm{Y}\right), \mathrm{i}=1, \ldots, \mathrm{N}
$$

\footnotetext{
${ }^{4}$ Barba-Navaretti et al. (2003) and Harrison and McMillan (2006) follow a similar procedure.
} 
We assume that labour supply is perfectly elastic and that employment changes are small. Thus taking logs on both sides of the equation gives a log-log relationship that may be estimated. In its simplest form, the empirical output-constrained labour demand specification with two inputs labour and capital, wage rate $\mathrm{w}_{\mathrm{it}}$ and cost of capital $\mathrm{r}_{\mathrm{it}}$ would take the following form (where $\sigma_{i t}$ is a white noise error term):

$$
\ln \left(l_{\text {it }}\right)=\beta \mathrm{w}_{\mathrm{it}}+\delta \mathrm{y}_{\mathrm{it}}+\eta \mathrm{r}_{\mathrm{it}}+\sigma_{\mathrm{it}}
$$

Given that labour demand is dynamic in nature (due to, for example, hiring and firing costs that make desired employment adjust only slowly) we introduce different adhoc lag structures in this specification. We also introduce a firm fixed effect $\left(v_{\mathrm{i}}\right)$ and time fixed effects $\left(\theta_{\mathrm{t}}\right)^{5}$ The latter are introduced to account for the fact that capital costs are not trivial to measure at the firm level. Therefore, we assume that the capital market is nationwide and changes in the cost of capital are captured by the time dummies. Our resulting specification may be written in the following form:

$$
\ln \left(1_{\mathrm{it}}\right)=\lambda \mathrm{l}_{\mathrm{it}-\mathrm{s}}+\beta \mathrm{w}_{\mathrm{it}}+\alpha \mathrm{y}_{\mathrm{it}}+v_{\mathrm{i}}+\theta_{\mathrm{t}}+\sigma_{\mathrm{it}}
$$

where, $1_{i t}$ denotes the employment level of firm $i$ at time $t$ and $s$ is the number of lags of the dependent variable (which is determined empirically). $\mathrm{w}_{\mathrm{it}}$ denotes the $\log$ of the average wage of firm $i$ at time $t$ and $y_{i t}$ is the log of total sales. Equation 3 is our starting point. Further empirical specifications are considered following this baseline specification. In the first specification conditional on output, we evaluate whether labour demand in

\footnotetext{
${ }^{5}$ Industry information is time invariant and relates to the last year in our data set. Hence, industry specific fixed effects are subsumed in the firm fixed effect. This is important, as industry fixed effects would capture the fact that foreign and domestic multinationals may locate in different industries.
} 
domestic and foreign multinationals differs in the magnitude of their wage and output elasticity:

$$
\begin{aligned}
1_{i t}= & \lambda 1_{i t-s}+\beta_{1} \mathrm{w}_{\text {it }}+\alpha_{1} \mathrm{y}_{\mathrm{it}}+\beta_{2}\left(\mathrm{w}_{\mathrm{it}} * \mathrm{DMNE}_{\mathrm{i}}\right) \\
& +\alpha_{2}\left(\mathrm{y}_{\mathrm{it}} * \mathrm{DMNE}_{\mathrm{i}}\right)+v_{\mathrm{i}}+\theta_{\mathrm{t}}+\sigma_{\mathrm{it}}
\end{aligned}
$$

The two interactions $\left(\mathrm{w}_{\mathrm{it}} * \mathrm{DMNE}_{\mathrm{i}}\right)$ and $\left(\mathrm{y}_{\mathrm{it}} * \mathrm{DMNE}_{\mathrm{i}}\right)$ permit the coefficients on the wage and output elasticities to differ by the nationality of multinational firms. Specifically, $\mathrm{DMNE}_{\mathrm{i}}$ is a dummy equal to 1 if the multinational is British owned; it is time invariant due to the nature of the data. Hence, intercept differences between domestic and foreign multinationals are captured by $v_{\mathrm{i}}$, our firm fixed effect.

Unfortunately, theory gives us limited guidance as there exists no refutable model that predicts how headquarter services should have a distinct effect through the direct skill intensive activities on labour demand elasticity. Thus, we introduce a second specification where we add two linear interaction terms $\left(\mathrm{w}_{\mathrm{it}} * \operatorname{skill}_{\mathrm{it}}\right)$ and $\left(\mathrm{y}_{\mathrm{it}} * \mathrm{skill}_{\mathrm{it}}\right)$,

$$
\begin{aligned}
1_{\text {it }}= & \lambda 1_{\text {it }-\mathrm{s}}+\beta_{1} \text { wage }_{\text {it }}+\alpha_{1} \text { sales }_{\text {it }}+\beta_{2}\left(\text { wage }_{i t} * \text { DDMNE }_{\mathrm{i}}\right) \\
& +\alpha_{2}\left(\text { sales }_{\mathrm{it}} * \mathrm{DMNE}_{\mathrm{i}}\right)+\beta_{3}\left(\text { wage }_{\mathrm{it}} * \text { skill }_{\mathrm{it}}\right) \\
& +\alpha_{3}\left(\text { sales }_{\mathrm{it}} * \text { skill }_{\mathrm{it}}\right)+\gamma \text { skill }_{\mathrm{it}}+v_{\mathrm{i}}+\theta_{\mathrm{t}}+\sigma_{\mathrm{it}}
\end{aligned}
$$

where skill ${ }_{i t}$ is our measure of skill intensity in firm $i$ at time $t$, defined in the data section. This specification may be justified by firm level skill intensity resulting from strong complementarities between workers within the same firm, as suggested by Kremer (1993). Therefore, according to Hamermesh (1993), we expect more skill intensive firms to exhibit lower wage elasticity of labour demand. This specification enables us, hence, to quantify 
the differences in wage elasticity for domestic and foreign multinational firms over and above a direct effect of skill intensity of production on labour demand elasticity.

We would expect the coefficient on $\mathrm{w}_{\mathrm{it}}$ to be negative and the coefficient of the interaction term $\left(\mathrm{w}_{\mathrm{it}} * \mathrm{DMNE}_{\mathrm{i}}\right)$ to be positive. In short, domestic multinational firms would have a smaller (in absolute terms) wage elasticity of labour demand than foreign multinational firms, even when controlling for the average skill intensity of production in a firm. This, we would argue, may be attributable to the higher intensity of headquarter services in a domestic multinational.

Estimating equations 3 to 5 with OLS would clearly result in endogeneity bias because wages, output and skill intensity may well be affected by employment changes. Also, the lagged dependent variable is related to the error term by construction. Therefore, we use the Systems GMM approach as suggested by Blundell and Bond (1998). This uses all existing lags of the dependent variable in levels and differences to generate additional orthogonality conditions.

\section{Data}

The FAME (Financial Analysis Made Easy) dataset provides extensive information on UK operations of domestic and foreign multinational firms. It is provided by Bureau van Dijk (BvDEP) and reports detailed yearly information on the activities of each firm. From the ownership section of the data we are able to construct a foreign ownership indicator for a firm. A firm is considered to be foreign if it is majority owned, wholly owned or the main known shareholder is foreign. Similarly, a domestic firm that controls or manages a firm located abroad is defined to be a domestic multinational. Another important variable that we use in our empirical analysis is the value of intangible assets. 
An important advantage of studying multinationals located in one country is that any difference in labour demand elasticity between foreign and domestic multinational firms should not be the result of different labour market institutions.

Given that data about small firms may be unreliable, we drop observations on firms that report less than 10 employees. $^{6}$ We are left with information for 1801 foreign multinational firms and 159 domestic multinationals over the 1996-2005 period. ${ }^{7}$ Our panel of firms is thus well adapted to studying small changes in employment and to quantifying measured differences in wage elasticities of labour demand for domestic and foreign multinational firms. ${ }^{8}$

Total sales and wages for each firm are directly extracted from the FAME dataset. Note that labour remunerations in each multinational consist of all salary costs including social security and pension costs. We deflate these raw values using a two-digit SIC level producer price index provided by the Office of National Statistics (ONS).

The FAME database does not provide any information on skills. Hence, we do not measure skill intensity in terms of worker characteristics such as education or occupation. Rather, we suggest measuring the average skill intensity in a firm as a firm's relative position in the wage distribution, based on the assumption that within an industry, this relative position provides information on skill intensity.

Specifically, the skill intensity variable is defined as follows:

$$
\text { Skill }_{\mathrm{it}}=\left(\text { AverageLabourCosts }_{\mathrm{it}}\right) /\left(\text { Median }_{\left(\text {wage }_{\mathrm{jt}}\right)}\right.
$$

\footnotetext{
6 This reduces the sample only slightly because FAME reports information over firms only if they have fixed assets, current assets, current liabilities or long term liabilities that are greater than $£ 150,000$.

${ }^{7}$ Note that we have fewer domestic multinationals than Criscuolo and Martin (2009). The reason is that we use the same unit of observation, i.e. the firm, to define a domestic multinational and for our empirical analysis. Criscuolo and Martin (2009) use firm level information to define domestic multinationals, but plants as the unit of observation for their empirical analysis. As firms might own more than one plant, they have a higher number of domestic MNEs per construction. We do not have plant level data available.

${ }^{8}$ Unfortunately, our dataset does not allow studying exit and entry behaviour of firms. The role of headquarter services in relation to exit or entry of firms is thus not considered.
} 
where the numerator is average labour costs in firm $i$ at time $t$ while the denominator is the median yearly gross wage paid to a full time worker in the firms' 2-digit SIC manufacturing industry $\mathrm{j}$ at time $\mathrm{t}$. The median wage is calculated using the British Household Panel Survey (BHPS) which is a representative sample of the UK population. Thus the denominator might be considered as a "hypothetical" wage for a representative worker in an industry. The numerator accounts for the fact that firms pay a skill premium to the average employee.

As a whole, our skill intensity measure reflects firm's total labour costs normalized by a hypothetical total labour costs that would occur if all employees where homogenous within each two-digit industry. ${ }^{9}$ This provides us with a skill intensity proxy that is observable at the firm level. It does not rely on grouping of employees according to their occupations, tasks or educational level and therefore avoids the problem that the definition of skills may differ considerably depending on which worker characteristic is used. ${ }^{10}$ However, it has to be considered as only an imperfect proxy for skill intensity as it is solely calculated through the lens of wages. ${ }^{11}$

One potential concern with this skill intensity measure is that it relies on the fact that higher wages in a firm are always related to higher skill intensity within an industry. However, we know from empirical studies that "strong" firms (in terms of productivity, size or export status) pay higher wages than others, and this is not necessarily due to skill

\footnotetext{
${ }^{9}$ Searching for alternative to traditional skill information is not new in the empirical international trade literature. Javorcik (2004) measures labour in terms of efficiency units by dividing firm level payroll over the contemporaneous minimum wage in order to take into account skill differences across firms. Head and Ries (2002) replace the non-production to production employee ratio by dividing the firm's wage bill over the mean national wage.

${ }^{10}$ Winchester et al. (2006), Hijzen et al. (2005) and Becker et al. (2005) all show that there are large discrepancies between skill measures based on occupation or education. Our measure calculates the skill intensity relative to other firms in each 2-digit industry.

${ }^{11}$ For example, Heyman et al. (2007) show that multinationals pay higher wages than domestic firms, even for individuals within the same educational category. However, this may be less of a problem for our analysis, as we only consider multinationals, not purely domestic firms.
} 
differences (e.g. Heyman et al. 2007 and Frías et al., 2011). In order to alleviate this concern, we propose a robustness check based on an alternative skill definition. This measure is generated from the residual from an OLS regression of $S k i l l_{i t}$ on observable firm level characteristics (productivity defined as output per worker, a dummy equal to one if a firm is an exporter, and 5 size dummies) and time dummies. ${ }^{12}$ We use this residual (RESskill $\left.{ }_{i t}\right)$ as an alternative measure of skills in the estimation of equation 5.

Table 1 shows average skill intensity measures as explained above for each 2-digit SIC 2003 industry in 1996 and in 2005. We observe first that the median skill intensity in our whole sample of multinationals slightly increased during the time period under study. Furthermore, domestic multinational firms seem in general to be more skill intensive, but not in all industries. In the last column of table 1 we additionally provide information on the share of domestic multinationals in our sample of multinationals to see whether domestic and foreign firms are unequally distributed in different industries. While in some industries such as "office machinery and other equipment" (SIC 30) the share of domestic multinationals is larger than the national wide average, in other industries it is slightly lower "Other transport equipment" (SIC 35) . Nevertheless, our sample of multinationals does not suggest large disparities in the distribution across industries between domestic and foreign multinationals and thus is unlikely of drive our econometric results. ${ }^{13}$

Our summary statistics are presented in Table 2. Domestic multinational firms in our sample do not seem to pay different average wages than foreign firms, in line with Criscuolo and Martin (2009). ${ }^{14}$ Furthermore, we observe some differences in the size of the respective firms in terms of average total sales and number of employees at this aggregated

\footnotetext{
${ }^{12}$ In this OLS regression we do not only consider multinationals in our sample, but include as well 1105 domestic firms. Those firms are not owned by any domestic or foreign multinational.

${ }^{13}$ The difference in industry dispersion between domestic and foreign multinationals is accounted for in the econometric estimation through the inclusion of firm fixed effects (which encompass industry fixed effects).

${ }^{14}$ The averages are also close to the mean wage found in UK firms in 1996 by Griffith and Simpson

(2003). Their study ends in 1996 so no possible comparison can be made for subsequent years.
} 
level. Domestic multinationals are slightly larger in our sample. Furthermore, the share of intangible assets is only available for fewer observations, which is probably due to the difficulty of evaluating the real value of intangible assets. Nonetheless, the mean of this variable reveals that domestic multinationals have much higher values for the share of intangible assets in their total sales than foreign multinational firms, which is consistent with their having higher levels of headquarter services. The data also show that some domestic and foreign firms have no intangible assets included in their account data. This suggests that such headquarter services in multinationals are not easy to measure precisely.

\section{Empirical results}

The first step of our econometric analysis is to let the data generation process define which lag dependent variable satisfies best our selection criteria in estimating equation 3. Column 1 of table 3 presents the regression results of equation 3 with s equal to 1 , i.e. the dependent variable enters the specification with one lag. The Arellano Bond AR(2) test (pvalue $=0.020$ ) can be rejected and the Hansen test of overidentification of the instruments can also be rejected by our data generation process. In column 2, we add one lag of the wage and output variable, but at the same time, we keep s equal to 1 . As before, our selection criteria are still not satisfied. In particular, the $\operatorname{AR}(2)$ test can be rejected by the data. In column 3 , we turn to a specification with s equal to 2 . The AR(2) test cannot be rejected at the 5 percent level $(\mathrm{p}$ value $=0.217)$. Furthermore, we cannot reject the hypothesis of instrument validity at the standard level of significance ( $p$-value $=0.59)$. Hence, according to our selection criterion the dependent variable enters our equation with two lags. The coefficients found in column 3 represent our baseline specification. ${ }^{15}$

\footnotetext{
${ }^{15}$ In table A1 in the appendix, we also compare different estimators (OLS, fixed effect and difference GMM) to our system GMM estimator. This comparison reinforces the superiority of our specification methodology. In particular, the magnitude of the first lag of the dependent variable is bounded between the coefficient of the fixed effect and OLS specifications. Roodman (2006) suggests that this is a sign of efficiency of the estimator.
} 
Concerning our coefficients, we obtain the expected signs for the variables in the labour demand equations. The coefficient of the logarithm of wages is negative and significant at the 1 per cent level. The logarithm of sales is also highly significant and positive. Turning to our variables of interest, the interaction term $\left(\mathrm{y}_{\mathrm{it}} * \mathrm{DMNE}_{\mathrm{i}}\right)$ is significant and negative and the coefficient of the interaction term $\left(\mathrm{w}_{\mathrm{it}} * \mathrm{DMNE}_{\mathrm{i}}\right)$ is also highly significant and positive. Thus, domestic multinationals seem to be on average less wage elastic (in absolute terms) than foreign multinational firms in the UK. ${ }^{16}$ A one percent increase in labour costs decreases demand for labour by 0.839 percent in foreign multinationals, while a one percent increase in the wage induces a 0.184 percent (calculated as $-0.839+0.655)$ decrease in the labour force demanded by domestic multinational. The results reported in table 3 thus appear supportive of our hypothesis that domestic multinationals have lower (in absolute terms) wage elasticity of labour demand. This finding is consistent with the idea that domestic multinationals' skill intensive headquarter services drive their employment behaviour in response to labour cost changes. ${ }^{17}$

We now estimate variants of equation 5 which allow multinational firms' labour demand elasticity to be heterogeneous according to their skill intensity. As pointed out above, we expect firms to have lower wage elasticities (in absolute terms) as their skill intensity increases. Results of these estimations are presented in column 1 of table 4 . The first column shows that the coefficient on wages is still negative and highly significant, while the interaction term $\left(\right.$ wage $_{i t} *$ Skill $_{i t}$ ) is positive and significant at the standard level of significance. Hence, more skill intensive multinationals have lower (in absolute terms) wage elasticities of labour demand, as expected.

\footnotetext{
${ }^{16}$ While the coefficients on the control variables are in line with the previous papers by Nilsson Hakkala (2010), Görg et al. (2009) and Barba Navaretti et al. (2003) we cannot compare the coefficients on the domestic multinational dummy with these earlier studies. This is because the earlier papers compare either multinationals (foreign and domestic) and non-multinationals or foreign and domestic (multinationals and non-multinationals) firms. We, by contrast, compare foreign to domestic multinationals.

${ }^{17}$ Table A2 in the appendix presents estimations of the same specification as in column (3) using OLS and FE estimators for comparison.
} 
The median skill intensity for a firm in our sample in 2005 in log terms is 0.265 . Multiplying this number by the coefficient of the interaction term, 0.524 , and adding the coefficient of wage elasticity, -0.99 , yields -0.851 . Ceteris paribus, a 1 percent increase in wages induces a 0.851 percent decrease in the labour demand of the median multinational firm. For a multinational firm at the 90th percentile, the direct effect of skill intensity on wage elasticity is even stronger with a wage elasticity of -0.634 percent. Thus, the sign and the magnitude of the coefficient of the interaction term (wage ${ }_{i t}{ }^{*}$ skill $_{i t}$ ) support strongly the idea that higher skill intensive firms have on average lower (in absolute value) labour demand wage elasticities.

This raises the question as to whether the observable skill intensity can explain the difference in wage elasticities between domestic and foreign multinationals. To look at this we estimate the model including both the interaction terms for skill intensity and for domestic multinationals. Results are shown in column 2 of table 4 . The coefficient on $\left(\mathrm{w}_{\mathrm{it}}\right.$ * $\mathrm{DMNE}_{\mathrm{i}}$ ) is still positive and significant while that on wage ${ }_{\mathrm{it}}$ is, as before also significant but negative. This suggests that observable skill intensity does not capture all aspects of headquarter services. On the other hand, the interaction term $\left(\right.$ wage $\left._{\mathrm{it}} * \mathrm{Skill}_{\mathrm{it}}\right)$ is still positive but becomes insignificant at the 5 percent level. Comparing these results with those found in column 3 of table 3 shows that both multinational types' labour demand becomes more wage elastic, the coefficient on wage $_{i t}$ being equal to 1.18. As a result, a one percentage point increase in labour costs decreases labour demand by 0.64 percent for domestic multinationals.

Column (3) presents a robustness check based on the alternative definition of skills as the residual from an OLS regression including firm characteristics as explanatory 
variables. Reassuringly, this alternative procedure provides very similar labour demand coefficients and strongly supports our earlier results. ${ }^{18}$

To check further the robustness of our results, we split our sample according to the size of the multinational firms, since Hamermesh and Pfann (1996) show that labour demand elasticities may depend on the size of the firm. Results are presented in table 5. Column 1 restricts our sample to multinational firms with more than 100 employees. In column 2, we consider only the sample of multinational firms with less than 500 employees and finally in column 3 we show results solely for multinational firms that employ between 100 and 500 employees. None of the sample size restrictions change our results in a significant way. However the magnitude of our main coefficients differs slightly as shown in table 5. Most importantly, however, size differences between domestic and foreign multinationals do not seem to drive our results.

As proposed above, intangible assets may also be related to skill intensity and headquarter services. Therefore we replace our skill intensity variable by a measure of intangible assets. Results including the intangible assets variable, measured as the share of total sales, are presented in table 6 . In column 1 , we observe that the coefficient on wage $\mathrm{it}_{\mathrm{it}}$ is negative and significant. Its magnitude is similar to the one found in the specification with our skill intensity proxy. However, an important difference is that the elasticity for domestic multinational firms is even more reduced than in the skill intensity case. Domestic multinational firms have now an elasticity of -0.21. It may suggest that intangible assets, evaluated at book prices, have an influence on the average labour demand by reducing the magnitude of the wage elasticity in domestic multinationals. However, they cannot explain the whole difference in elasticities between foreign and domestic multinationals. Hence,

\footnotetext{
${ }^{18}$ In an additional robustness check, we allowed a distinct effect of skill intensity for domestic and foreign multinationals by introducing a triple interaction term (wage ${ }_{\mathrm{it}} * \mathrm{DMNE}_{\mathrm{i}} * \mathrm{Skill}_{\mathrm{it}}$ ). This leads to all interaction terms being statistically insignificant, which confirms our presumption that skill intensity and headquarter services are intertwined in domestic multinationals. We therefore favour our specifications without the triple interaction term.
} 
other aspects of headquarter services, not captured by our intangible assets proxy, like organizational capacities to manage and control foreign affiliates may still drive a significant part of this difference.

After establishing the robustness of our results we now turn to compute the quantitative importance of our estimates. We calculate the difference in the wage elasticity between domestic multinationals and foreign multinationals, divided by the wage elasticity coefficient for foreign multinational firms. In other words, the percent difference between the elasticity for domestic firms and that for foreign firms. This calculation is presented in table 7 and is based on results extracted from tables 3 to 6 .

To illustrate the findings of the table, consider column (1) in Table 7. Coefficient results from table 3, column 3 indicate that the wage elasticity for domestic multinationals is 22 percent lower than that for foreign firms. However, this may be biased as it does not account for observable skill intensity differences. For this reason, we use the wage elasticities obtained from tables 4 and 5, where the direct skill intensity effect on labour demand elasticity is accounted for. In table 4, column 2, the wage elasticity for foreign multinationals was -1.183 compared to -0.642 for domestic multinationals. Thus domestic multinationals' labour demand elasticity is about 54 percent lower (column 2 of Table 7). The difference (22 versus 54 percent) shows that omitting the direct role of skill intensity, underestimates the difference in labour demand elasticities. One possible explanation may be that foreign multinationals have a highly skill intensive production process. The average difference from all estimations is presented in column (9). On average, we find that the wage elasticity for domestic multinationals is 42 percent lower than that in foreign multinationals.

\section{Conclusions}


We find that domestic multinationals' labour demand is less sensitive to wage shocks than foreign multinationals'. Our results are based on labour demand elasticities of domestic and foreign UK operations of multinationals during the period from 1996 to 2005. These results hold even when we allow for different skill intensities of the operations of the two types of firms. They are also robust to taking account of intangible assets in the calculation of the role of headquarter services on labour demand elasticity. These results are consistent with the idea that headquarter services are important in shaping domestic multinational's labour demand response to own wage shocks. The wage elasticity of labour demand is about 40 percent lower in domestic than in foreign multinationals.

Our results point to a possible concern for policy makers regarding the relationship between labour demand and multinational firms. Anecdotal evidence suggests that global firms like IBM have recently increased their R\&D and headquarter activities in India (The Economist, 2007). Toyota intends to share more control power and give more independence to its foreign affiliates (International Herald Tribune, 2008). Assuming that headquarter services reflect at least part of the difference in wage elastictities, then our results suggest that the location of headquarter services may have important consequences for labour demand behaviour in multinational firms. 


\section{References}

Barba-Navaretti, G.,Checchi, D. and Turrini, A. (2003).'Adjusting Labor Demand: Multinational Versus National Firms: A Cross-European Analysis',Journal of the European Economic Association, 1, pp. 708-719.

Becker, S.,Ekholm, K.,Jäckle, R. and Mündler, M. (2005).'Location Choice and Employment Decisions: A Comparison of German and Swedish Multinationals', Review of World Economics,141, pp. 693-731.

Blundell, R. and Bond, S. (1998). 'Initial Conditions and Moment Restrictions in Dynamic Panel Data Models',Journal of Econometrics, 87, pp. 115-143.

Criscuolo, C. and Martin, R. (2009). 'Multinationals and US productivity Leadership: Evidence from Great Britain', Review of Economics and Statistics, 91, pp. 263-281.

Davies, R. (2005). 'Fragmentation of Headquarter Services and FDI', North American Journal of Economics and Finance, 16, pp. 61-79.

Economist (2007).Hungry Tiger, Dancing Elephant, The Economist Group, April, $4^{\text {th }}$.

Frías, J., Kaplan, D. and Verhogen A. (2011). 'Exports and Wage Premia: Evidence from Mexican Employer- Employee Data, Working Paper, Columbia University.

Görg, H., Henry, M., Strobl, E. and Walsh, F. (2009). 'Multinational Companies, Backward Linkages, and Labour Demand Elasticities, Canadian Journal of Economics,42, pp. 332348.

Griffith, R. and Simpson, H. (2003).Characteristics of Foreign-Owned Firms in British Manufacturing, NBER Working Paper 9573.

Hamermesh, D. (1993).Labor Demand, Princeton University Press.

Hamermesh, Daniel S. and Gerard Pfann (1996), Adjustment costs in factor demand, Journal of Economic Literature, 34, 1264-1292.

Hanson, G., Mataloni, R. and Slaughter, M. (2005).Vertical production networks in multinational firms, Review of Economics and Statistics, 87, 664-678.

Harrison, A. and McMillan, M. (2006).Outsourcing Jobs? Multinationals and U.S. Employment, NBER Working Paper 12372.

Head, K. and Ries, J. (2002) 'Offshore Production and Skill Upgrading by Japanese Manufacturing Firms', Journal of International Economics,58, pp. 81-105.

Helpman, E. (1985) 'Multinational Corporations and Trade Structure', Review of Economic Studies, 52, 443-457.

Helpman, E., M.J. Melitz and S.R. Yeaple (2004) "Export versus FDI with heterogeneous firms" American Economic Review, 94, 300-316.

Heyman, F., F. Sjöholm and P. Gustavsson Tingvall (2007). "Is there really a foreign ownership wage premium? Evidence from matched employer-employee data", Journal of International Economics, 73, 355-376.

Hijzen, A., Görg, H., and Hine, R. (2005). 'International Outsourcing and the Skill Structure of Labour Demand in the United Kingdom'Economic Journal, 115, pp. 860-878.

Horst, T. (1978) 'The Impact of American Investments Abroad on U. S. Exports, Imports and Employment', in The Impact of International Trade and Investment on Employment,US Gov. Print. Off. 
International Herald Tribune (2008).At Toyota, a Global Giant Reaches for Agility,February, $4^{\text {th }}$.

Javorcik, B.S. (2004), "Does Foreign Direct Investment Increase the Productivity of Domestic Firms? In Search of Spillovers through Backward Linkages", American Economic Review.

Lipsey, R. (2008). Measuring the Location of Production in a World of Intangible Productive Assets, FDI, and Intrafirm Trade, NBER Working Paper 14121.

Markusen, J. (2002).Multinational Firms and the Theory of International Trade, MIT Press.

Nilsson Hakkala, K., F. Heyman and F. Sjöholm (2010). "Multinationals, skills, and wage elasticities" Review of World Economics, 146, 263-280.

Rodrik, D. (1997). Has Globalization gone too far?, Institute for International Economics.

Roodman, D. (2006). How to Do xtabond2: An Introduction to "Difference" and "System" GMM in Stata, Working Papers 103, Center for Global Development.

Scheve, K. and Slaughter, M. (2004). 'Economic Insecurity and the Globalization of Production', American Journal of Political Science,48, pp. 662-674.

Winchester, N. and Greenaway, D. (2006). Skill classification and the effect of trade on wage inequality', Review of World Economics, 142, pp. 287-306. 


\section{Appendix}

Table A1: Labour demand elasticities with different estimators

\begin{tabular}{|c|c|c|c|c|c|c|c|c|}
\hline \multirow[t]{2}{*}{ Dep Var. } & \multicolumn{8}{|c|}{ employment $_{t}$ (in log.) } \\
\hline & $(1)$ & $(2)$ & (3) & (4) & $(5)$ & (6) & (7) & $(8)$ \\
\hline & OLS & Fix. Eff. & Dif. GMM & Sys. GMM & OLS & Fix. Eff. & Dif. GMM & Sys GMM \\
\hline \multirow[t]{2}{*}{ employment $_{t-1}$} & $0.891 * * *$ & $0.541 * * *$ & $0.175^{* *}$ & $0.544^{* * *}$ & $1.054^{* * *}$ & $0.584 * * *$ & $0.566 * *$ & $0.960 * * *$ \\
\hline & $(0.006)$ & $(0.015)$ & $(0.070)$ & $(0.101)$ & $(0.016)$ & $(0.022)$ & $(0.285)$ & $(0.146)$ \\
\hline \multirow{2}{*}{ employment $_{t-2}$} & -- & -- & -- & -- & $-0.163^{* * *}$ & $-0.100 * * *$ & 0.083 & -0.086 \\
\hline & -- & -- & -- & -- & $(0.015)$ & $(0.013)$ & $(0.094)$ & $(0.102)$ \\
\hline \multirow[t]{2}{*}{ sales $_{t}$} & $0.508 * * *$ & $0.370 * * *$ & $0.653 * * *$ & $0.424 * * *$ & $0.098 * * *$ & $0.386 * * *$ & 0.174 & $0.147^{* *}$ \\
\hline & $(0.019)$ & $(0.018)$ & $(0.141)$ & $(0.102)$ & $(0.005)$ & $(0.020)$ & $(0.306)$ & $(0.063)$ \\
\hline \multirow[t]{2}{*}{ wages $_{t}$} & $-0.539 * * *$ & $-0.483 * * *$ & $-0.647 * *$ & $-0.933 * * *$ & $-0.169 * * *$ & $-0.500 * * *$ & $-0.819 * *$ & $-0.335^{* *}$ \\
\hline & $(0.020)$ & $(0.024)$ & $(0.271)$ & $(0.137)$ & $(0.011)$ & 0.024 & $(0.301)$ & $(0.159)$ \\
\hline Time dummies & yes & yes & yes & yes & yes & yes & yes & yes \\
\hline Nb. Obs. & 17590 & 17590 & 15620 & 17590 & 15667 & 15667 & 13702 & 15667 \\
\hline $\mathrm{Nb}$. Of groups & -- & -- & 1960 & 1960 & -- & -- & 1960 & 1960 \\
\hline$A R(1)$ & -- & -- & $-2.48 * *$ & $-5.74 * * *$ & -- & -- & -1.50 & $-3.39 * * *$ \\
\hline$A R(2)$ & -- & -- & $-2.17 * *$ & $-4.38 * * *$ & -- & -- & $-1.84^{*}$ & -0.46 \\
\hline$A R(2) p$-value & -- & -- & $(0.03)$ & $(0.000)$ & -- & -- & $(0.065)$ & $(0.644)$ \\
\hline Hansen J & -- & -- & 27.62 & $103.41^{* * *}$ & -- & -- & 16.38 & 36.4 \\
\hline Hansen J p-value & -- & -- & $(0.189)$ & $(0.000)$ & -- & -- & $(0.291)$ & $(0.114)$ \\
\hline
\end{tabular}


Table A2: Estimation of specification in column (3), Table 3 using alternative estimators

\begin{tabular}{|l|l|l|}
\hline Dep Var. & \multicolumn{2}{|l|}{ employment } \\
& (in log. $)$ \\
\hline & $(1)$ & $(2)$ \\
\hline & OLS & Fix. Eff. \\
\hline employment $_{t-1}$ & $1.055^{* * *}$ & $0.596^{* * *}$ \\
\hline & $(0.016)$ & $(0.020)$ \\
\hline employment $_{t-2}$ & $-0.163^{* * *}$ & $-0.100^{* * *}$ \\
\hline & $(0.014)$ & $(0.111)$ \\
\hline & $0.100^{* * *}$ & $0.394^{* * *}$ \\
\hline sales $_{t}$ & $(0.006)$ & $(0.021)$ \\
\hline & $-0.172^{* * *}$ & $-0.506^{* * *}$ \\
\hline wages $_{t}$ & $(0.011)$ & $(0.025)$ \\
\hline wages $_{t} * D M N E$ & $0.025^{* *}$ & $0.125^{* * *}$ \\
\hline & $(0.007)$ & $(0.030)$ \\
\hline sales $_{t} * D M N E$ & $-0.024^{* * *}$ & $-0.119^{* *}$ \\
\hline & $(0.007)$ & $(0.037)$ \\
\hline Time dummies & yes & yes \\
\hline Nb. Obs. & 15620 & 15620 \\
\hline Nb. Of groups & 1960 & 1960 \\
\hline
\end{tabular}

Robust standard errors in brackets; significant at the 1 percent level (***), 5 percent level (**), 10 percent level (*). DMNE is a dummy equal to 1 if a firm is a UK owned domestic multinational 
Table 1: Average skill intensity and distribution of domestic and foreign multinationals in 2-digit SIC (2003) industry in the UK

\begin{tabular}{|l|l|l|l|l|c|}
\hline SIC & \multicolumn{3}{|c|}{ Skill intensity (BHPS) } & Share of DMNE \\
\hline & \multicolumn{2}{|c|}{1996} & \multicolumn{2}{c|}{2005} & 2005 \\
\hline & FMNE & DMNE & FMNE & DMNE & \\
\hline $\begin{array}{l}\text { 15-16 Manufacturing of food products and } \\
\text { beverages }\end{array}$ & 1.51 & 2.17 & 1.38 & 1.83 & 8.72 \\
\hline 18 Wearing apparel & 1.97 & 1.98 & 1.93 & 2.47 & 11.54 \\
\hline 20 Wood and wood products & 1.37 & 1.39 & 1.11 & 1.31 & 7.41 \\
\hline 21 Pulp and paper products & 1.12 & 1.15 & 1.64 & 1.73 & 4.29 \\
\hline 22 Publishing and printing & 1.41 & 1.57 & 1.72 & 2.43 & 6.74 \\
\hline 24 Chemicals & 1.40 & 1.32 & 1.45 & 1.41 & 11.11 \\
\hline 25 Rubber and plastic & 1.21 & 1.24 & 1.43 & 1.60 & 9.77 \\
\hline 26 Other non-metallic mineral products & 1.41 & 1.24 & 1.47 & 1.25 & 4.11 \\
\hline 27 Basic metals & 1.40 & 1.26 & 1.27 & 1.13 & 7.14 \\
\hline 28 Fabricated metal products & 1.26 & 1.41 & 1.34 & 1.62 & 7.58 \\
\hline 29 Machines and other equipment & 1.41 & 1.52 & 1.31 & 1.47 & 9.95 \\
\hline 30 Office machinery and other equipment & 1.84 & 1.95 & 1.50 & 1.78 & 16.67 \\
\hline 31 Electronic machinery and apparatus n.e.c & 1.29 & 1.28 & 1.77 & 2.15 & 10.3 \\
\hline 32 Radio and television & 1.12 & 1.13 & 1.38 & 1.31 & 12.16 \\
\hline 33 Medical, precision and optical instruments & 1.21 & 1.20 & 1.25 & 1.24 & 11.38 \\
\hline 34 Motor vehicles and trailers & 1.08 & 1.02 & 1.30 & 1.01 & 5.77 \\
\hline 35 Other transport equipment & 1.26 & 1.39 & 1.14 & 1.63 & 2.27 \\
\hline 36 Furniture and manufacture n.e.c. & 1.59 & 1.49 & 1.44 & 1.25 & 3.48 \\
\hline total & 1.37 & 1.46 & 1.45 & 1.66 & 8.83 \\
\hline
\end{tabular}

DMNE are domestic multinational firms, while FMNE are foreign multinational firms. The column Skill intensity (BHPS) uses information from the British Household panel survey to calculate average industry level skill intensity. The share of DMNE is the share of domestic multinationals in total multinationals located in the UK. 
Table 2: Summary statistics on multinationals active in the UK (Domestic MNEs and foreign MNEs)

\begin{tabular}{|l|l|l|l|l|l|l|l|}
\hline & & $\begin{array}{l}\text { Nb. } \\
\text { Of } \\
\text { obs. }\end{array}$ & mean & Std. Dev. & median & min & max \\
\hline FMNE & Employees & 18010 & 354 & 1053 & 121 & 10 & 30300 \\
\hline DMNE & Employees & 1590 & 978 & 4245 & 275 & 16 & 65300 \\
\hline FMNE & $\begin{array}{l}\text { Wage per head in } \\
\text { (f, 1996) }\end{array}$ & 17165 & 28169 & 9481 & 25784 & 6426 & 96103 \\
\hline DMNE & $\begin{array}{l}\text { Wage per head in } \\
\text { (f, 1996) }\end{array}$ & 1530 & 25784 & 10325 & 28169 & 7985 & 88041 \\
\hline FMNE & Skill intensity & 17165 & 1.37 & 6.49 & 1.30 & 0.43 & 7.54 \\
\hline DMNE & Skill intensity & 1530 & 1.49 & 6.55 & 1.39 & 0.44 & 4.53 \\
\hline FMNE & $\begin{array}{l}\text { UK output (f, } \\
1000,1996)\end{array}$ & 17938 & 60309 & 299 & 13446 & 1022 & 8416288 \\
\hline DMNE & $\begin{array}{l}\text { UK output (f, } \\
\text { 1000, 1996) }\end{array}$ & 1586 & 157283 & 798 & 31932 & 1374 & 9544555 \\
\hline FMNE & $\begin{array}{l}\text { Share of intangible } \\
\text { assets in total } \\
\text { sales }\end{array}$ & 13457 & 0.04 & 0.56 & 0.00 & 0.00 & 50.9 \\
\hline $\begin{array}{l}\text { Share of intangible } \\
\text { assets in total } \\
\text { sales }\end{array}$ & 1253 & 0.19 & 1.68 & 0.01 & 0.00 & 30.6 \\
\hline
\end{tabular}

DMNE are domestic multinational firms. FMNE are foreign multinational firms 
Table 3: Labour demand elasticity and the nationality o multinationals in the UK from 1997 to 2005, 2 step System GMM estimation with different lag structures

\begin{tabular}{|c|c|c|c|c|}
\hline Dep. var & \multicolumn{4}{|c|}{ employment $_{t}($ in log) } \\
\hline specification & (1) & (2) & (3) & (4) \\
\hline $\mathrm{Nb}$. of firms & 1960 & 1960 & 1960 & 1960 \\
\hline \multirow[t]{2}{*}{ employment $_{t-1}$} & $0.309 * * *$ & $0.349 * * *$ & $0.746 * * *$ & $0.960 * * *$ \\
\hline & $(0.097)$ & $(0.144)$ & $(0.162)$ & $(0.146)$ \\
\hline \multirow[t]{2}{*}{ employment $_{t-2}$} & -- & -- & 0.015 & -0.086 \\
\hline & -- & -- & $(0.098)$ & $(0.102)$ \\
\hline \multirow[t]{2}{*}{ sales $_{t}$} & $0.687 * * *$ & $0.706^{* * *}$ & $0.303 * * *$ & $0.147^{* *}$ \\
\hline & $(0.124)$ & $(0.148)$ & $(0.103)$ & $(0.063)$ \\
\hline \multirow[t]{2}{*}{ sales $_{t-1}$} & -- & -0.095 & -- & -- \\
\hline & -- & $(0.236)$ & -- & -- \\
\hline \multirow[t]{2}{*}{ wages $_{t}$} & $-1.570 * * *$ & $-1.238 * *$ & $-0.839 * * *$ & $-0.335 * *$ \\
\hline & $(0.189)$ & $(0.270)$ & $(0.323)$ & $(0.159)$ \\
\hline \multirow[t]{2}{*}{ wages $_{t-1}$} & -- & $-0.535^{*}$ & -- & -- \\
\hline & -- & $(0.308)$ & -- & -- \\
\hline \multirow[t]{2}{*}{ wages $_{t} * D M N E$} & $0.841 * *$ & $0.836^{* *}$ & $0.655^{* *}$ & -- \\
\hline & $(0.214)$ & $(0.276)$ & $(0.293)$ & -- \\
\hline \multirow[t]{2}{*}{ sales $_{t} * D M N E$} & $-0.733 * *$ & $-0.705^{* *}$ & $-0.619 * *$ & -- \\
\hline & $(0.215)$ & $(0.266)$ & $(0.283)$ & -- \\
\hline time dummies & yes & yes & yes & yes \\
\hline $\mathrm{Nb}$. of obs. & 17590 & 16665 & 15667 & 15667 \\
\hline $\mathrm{AR}(1)$ & $-5.55 * * *$ & -1.09 & $-2.92 * * *$ & $-3.39 * * *$ \\
\hline AR(1)p-value & $(0.000)$ & $(0.278)$ & $(0.004)$ & $(0.001)$ \\
\hline $\mathrm{AR}(2)$ & $-2.33 * *$ & $-2.87 * * *$ & -1.23 & -0.46 \\
\hline AR(2) p-value & $(0.020)$ & $(0.004)$ & $(0.217)$ & $(0.644)$ \\
\hline Hansen test & $50.14 * *$ & 41.21 & 20.85 & 36.04 \\
\hline Hansen test p-value & $(0.047)$ & $(0.292)$ & $(0.590)$ & $(0.114)$ \\
\hline
\end{tabular}

Robust standard errors in brackets; significant at the 1 percent level (***), 5 percent level (**), 10 percent level (*). DMNE is a dummy equal to 1 if a firm is a UK owned domestic multinational 
Table 4: Labour elasticity, skill intensity and the nationality of multinational firms, 1997-2005, 2 step system GMM estimation

\begin{tabular}{|c|c|c|c|}
\hline dep. var. & \multicolumn{3}{|c|}{ employment $_{t}($ in log. $)$} \\
\hline specification & $(1)$ & (2) & (3) \\
\hline $\mathrm{Nb}$. of firms & 1960 & 1960 & 1960 \\
\hline employment $_{t-1}$ & $0.922 * * *$ & $0.708^{* * *}$ & $0.516^{* * *}$ \\
\hline & $(0.128)$ & $(0.156)$ & $(0.152)$ \\
\hline employment $_{t-2}$ & 0.022 & 0.036 & 0.065 \\
\hline & $(0.097)$ & 0.093 & $(0.080)$ \\
\hline sales $_{t}$ & 0.142 & $0.302 * *$ & $0.409 * * *$ \\
\hline & $(0.088)$ & $(0.126)$ & $(0.122)$ \\
\hline wages $_{t}$ & $-0.990 * * *$ & $-1.183 * *$ & $-1.735 * * *$ \\
\hline & $(0.307)$ & $(0.500)$ & $(0.460)$ \\
\hline wages $_{t} * D M N E$ & -- & $0.541 * *$ & $0.472^{* *}$ \\
\hline & -- & $(0.236)$ & $(0.229)$ \\
\hline sales $_{t} * D M N E$ & -- & $-0.490 * *$ & $-0.398^{*}$ \\
\hline & -- & $(0.232)$ & $(0.221)$ \\
\hline wages $_{t} *$ skill $_{t}$ & $0.524 * * *$ & 0.043 & -- \\
\hline & $(0.255)$ & $(0.270)$ & \\
\hline sales $_{t} *$ skill $_{t}$ & 0.036 & 0.028 & -- \\
\hline & $(0.049)$ & $(0.050)$ & \\
\hline skill $_{t}$ & $-5.258^{* *}$ & -0.436 & -- \\
\hline & $(2.690)$ & $(2.688)$ & \\
\hline wages $_{t} *$ RESskill $_{t}$ & -- & -- & -0.326 \\
\hline & & & $(0.202)$ \\
\hline wages $_{t} *$ RESskill $_{t}$ & -- & -- & 0.052 \\
\hline & & & $(0.040)$ \\
\hline RESskill $_{t}$ & -- & -- & 3.454 \\
\hline & & & $(2.231)$ \\
\hline time dummies & yes & yes & yes \\
\hline Nb. of obs. & 15667 & 15667 & 15667 \\
\hline $\operatorname{AR}(1)$ & $-3.57 * * *$ & $-3.07 * * *$ & $-4.55 * * *$ \\
\hline AR(1)p-value & $(0.000)$ & $(0.002)$ & $(0.000)$ \\
\hline $\mathrm{AR}(2)$ & $-1.46^{* *}$ & -1.60 & -1.45 \\
\hline AR(2) p-value & $(0.145)$ & $(0.110)$ & $(0.147)$ \\
\hline Hansen test & 25.50 & 16.65 & 17.05 \\
\hline Hansen test p-value & $(0.435)$ & $(0.675)$ & $(0.587)$ \\
\hline
\end{tabular}

Robust standard errors in brackets; significant at the 1 percent level $(* * *), 5$ percent level $(* *), 10$ percent level $(*)$. DMNE is a dummy equal to 1 if a firm is a UK owned domestic multinational. Our skill intensity measure is: $\operatorname{skill}_{\mathrm{it}}=\left(\right.$ AverageLabourCosts $\left._{\mathrm{it}}\right) /\left(\right.$ Median $_{\left(\text {wage }_{\mathrm{it}}\right)}$, where the Median $\left(\right.$ wage $\left._{\mathrm{jt}}\right)$ ), is obtained from the BHPS (see text for more details) RESskill $l_{\mathrm{t}}$ is the residual obtained from an OLS regression of skill $1_{\mathrm{it}}$ on firm level characteristics (productivity and 5 employment-size dummies). Other covariates include time dummies and a dummy for export status. 
Table 5: labour demand elasticities, skill intensity and the nationality of multinational firms by group size, 2-step System GMM estimations

\begin{tabular}{|c|c|c|c|c|}
\hline Dep. var & \multicolumn{4}{|c|}{ employment $_{t}($ in log) } \\
\hline specification & (1) & (2) & (3) & (4) \\
\hline $\mathrm{Nb}$. of firms & 1362 & 1410 & 1166 & 1960 \\
\hline $\mathrm{Nb}$ of employees: $\mathrm{n}$ & $\mathrm{n}>100$ & $\mathrm{n}<500$ & $100<\mathrm{n}<500$ & All \\
\hline employment $_{t-1}$ & $0.764 * * *$ & $0.586^{* * *}$ & $0.704 * * *$ & $0.708 * * *$ \\
\hline & $(0.190)$ & $(0.178)$ & $(0.180)$ & $(0.156)$ \\
\hline employment $_{t-2}$ & -0.019 & -0.012 & 0.004 & 0.036 \\
\hline & $(0.102)$ & $(0.093)$ & $(0.102)$ & $(0.093)$ \\
\hline sales $_{t}$ & $0.320 * *$ & $0.474 * *$ & $0.322 * *$ & $0.302 * *$ \\
\hline & $(0.137)$ & $(0.196)$ & $(0.144)$ & $(0.126)$ \\
\hline wages $_{t}$ & $-1.086^{* *}$ & $-1.030 * *$ & $-1.169 * *$ & $-1.183 * *$ \\
\hline & $(0.531)$ & $(0.512)$ & $(0.505)$ & $(0.500)$ \\
\hline wages $_{t} * D M N E$ & $0.525 * *$ & $0.625 * *$ & $0.644 * *$ & $0.541 * *$ \\
\hline & $(0.259)$ & $(0.263)$ & $(0.257)$ & $(0.236)$ \\
\hline sales $_{t} * D M N E$ & $-0.473^{*}$ & $-0.531^{*}$ & $-0.563 * *$ & $-0.490 * *$ \\
\hline & $(0.261)$ & $(0.302)$ & $(0.267)$ & $(0.232)$ \\
\hline wages $_{t} *$ skill $_{t}$ & 0.233 & -0.141 & -0.206 & 0.043 \\
\hline & $(0.339)$ & $(0.338)$ & $(0.270)$ & $(0.270)$ \\
\hline sales $_{t} *$ skill $_{t}$ & $0.078^{*}$ & -0.082 & -0.030 & 0.028 \\
\hline & $(0.042)$ & $(0.111)$ & $(0.137)$ & $(0.050)$ \\
\hline skill $_{t}$ & -3.079 & 2.102 & 2.514 & -0.436 \\
\hline & $(3.434)$ & $(3.948)$ & $(3.240)$ & $(2.688)$ \\
\hline time dummies & yes & yes & yes & yes \\
\hline $\mathrm{Nb}$ of obs. & 10889 & 14100 & 9322 & 15667 \\
\hline $\mathrm{AR}(1)$ & $-2.93 * * *$ & $-3.40 * * *$ & $-3.06 * * *$ & $-3.07 * * *$ \\
\hline AR(1)p-value & $(0.003)$ & $(0.001)$ & $(0.002)$ & $(0.002)$ \\
\hline $\mathrm{AR}(2)$ & -1.25 & -0.71 & -0.92 & -1.60 \\
\hline AR(2) p-value & $(0.210)$ & $(0.476)$ & $(0.355)$ & $(0.110)$ \\
\hline Hansen test & 21.85 & 15.99 & 14.50 & 16.65 \\
\hline Hansen test p-value & $(0.530)$ & $(0.816)$ & $(0.804)$ & $(0.675)$ \\
\hline
\end{tabular}

Robust standard errors in brackets; significant at the 1 percent level (***), 5 percent level (**), 10 percent level (*). DMNE is a dummy equal to 1 if a firm is a UK owned domestic multinational 
Table 6: Labour demand elasticities, intangible assets, and the nationality of multinationals, 1997-2005, 2-step system GMM estimations

\begin{tabular}{|c|c|c|}
\hline Dep. Var. & \multicolumn{2}{|c|}{ employment $_{t}$ (in log.) } \\
\hline Specification & $(1)$ & (2) \\
\hline $\mathrm{Nb}$. of firms & 1866 & 1866 \\
\hline employment $_{t-1}$ & $0.564 * * *$ & $0.607 * * *$ \\
\hline & $(0.188)$ & $(0.219)$ \\
\hline employment $_{t-2}$ & 0.038 & 0.012 \\
\hline & $(0.098)$ & $(0.111)$ \\
\hline sales $_{t}$ & $0.442 * * *$ & $0.410^{* *}$ \\
\hline & $(0.155)$ & $(0.187)$ \\
\hline wages $_{t}$ & $-1.265 * * *$ & $-1.574 * *$ \\
\hline & $(0.419)$ & $(0.730)$ \\
\hline wages $_{t} * D M N E$ & $1.054^{* *}$ & $0.963^{* *}$ \\
\hline & $(0.455)$ & $(0.463)$ \\
\hline sales $_{t} * D M N E$ & $-0.990 * *$ & $-0.891 *$ \\
\hline & $(0.447)$ & $(0.461)$ \\
\hline Intang $_{t}$ & -0.151 & -1.052 \\
\hline & (1.228) & $(1.276)$ \\
\hline wages $_{t} *$ Intang $_{t}$ & -0.008 & 0.092 \\
\hline & $(0.129)$ & \\
\hline sales $_{t} *$ Intang $_{t}$ & 0.024 & -- \\
\hline & $(0.039)$ & -- \\
\hline wages $_{t} *$ skill $_{t}$ & -- & 0.054 \\
\hline & & $(0.322)$ \\
\hline sales $_{t} *$ skill $_{t}$ & -- & 0.061 \\
\hline & & $(0.070)$ \\
\hline $\operatorname{skill}_{t}$ & -- & -0.833 \\
\hline & & $(3.087)$ \\
\hline Time dummies & yes & yes \\
\hline $\mathrm{Nb}$ of obs. & 14536 & 14536 \\
\hline $\mathrm{AR}(1)$ & $-3.00^{* * *}$ & $-2.74 * * *$ \\
\hline AR(1)p-value & $(0.003)$ & $(0.006)$ \\
\hline $\mathrm{AR}(2)$ & $-1.33 * *$ & -0.89 \\
\hline AR(2) p-value & $(0.185)$ & $(0.373)$ \\
\hline Hansen test & $11.69^{* *}$ & 9.63 \\
\hline Hansen test p-value & $(0.702)$ & $(0.724)$ \\
\hline
\end{tabular}

Robust standard errors in brackets; significant at the 1 percent level (***), 5 percent level (**), 10 percent level (*). DMNE is a dummy equal to 1 if a firm is a UK owned domestic multinational 
Table 7: By how much are wage elasticities of labour demand smaller in absolute value for domestic MNEs than for foreign MNEs?

\begin{tabular}{|l|l|l|l|l|l|l|l|l|l|}
\hline & $(1)$ & $(2)$ & $(3)$ & $(4)$ & $(5)$ & $(6)$ & $(7)$ & $(8)$ & $(9)$ \\
\hline Calculated from table (t) and column (c) & $\mathrm{t} 3 \mathrm{c} 3$ & $\mathrm{t} 4 \mathrm{c} 2$ & $\mathrm{t} 4 \mathrm{c} 3$ & $\mathrm{t} 5 \mathrm{c} 1$ & $\mathrm{t} 5 \mathrm{c} 2$ & $\mathrm{t} 5 \mathrm{c3}$ & $\mathrm{t} 6 \mathrm{c1}$ & t6c2 & Average \\
\hline Control for skill intensity & no & yes & yes & yes & yes & yes & no & yes & -- \\
\hline Control for intangible assets & no & no & no & no & no & no & yes & yes & -- \\
\hline Size of multinationals (n) & all & all & all & $\mathrm{n}>100$ & $\mathrm{n}<500$ & $100<\mathrm{n}<500$ & all & all & -- \\
\hline $\begin{array}{l}\text { Differential in wage elasticties between } \\
\text { foreign and domestic MNEs (percentage) }\end{array}$ & 22 & 54 & 72 & 52 & 39 & 45 & 19 & 39 & 42 \\
\hline
\end{tabular}

